\title{
EDIBLE FLOWERS - THE ROSE
}

\author{
Attila Nagy ${ }^{1}$, Károly Ecseri ${ }^{1 *}$ \\ ${ }^{1}$ Department of Horticulture, Faculty of Horticulture and Rural Development, John von Neumann University \\ https://doi.org/10.47833/2020.2.AGR.011
}

\section{Keywords:}

polyphenol

antioxidant

functional food

edible ornamental plant

\section{Article history:}

Received 10 Nov 2019

Revised 26 Feb 2020

Accepted 10 March 2020

\begin{abstract}
Besides the importance of roses in amenity horticulture, medicine, history, economics and art, we examined the use of petals in the food industry, based on professional literature data. Among the edible roses, Rosa rugosa has an extremely high natural antioxidant capacity and antiproliferative effect in case of some cancers. Rosa chinensis has a high content of soluble free phenol and flavonoids and also has a high free radical scavenging ability. The macro- and micronutrient content is low in Rosa odorata petals, but it can be used as functional food like the other 100-200 species. Petals can be used to make jam, rose water, rose wine and sorbet, but can also be used as candy, as a jelly, for desserts and food decoration, as well as for punches, salads and fruits.
\end{abstract}

\section{Botanical presentation of the genus Rosa}

The name of the plants first appeared in ancient Rome. The word is probably derived from the pink flower of the genus because nearly $80 \%$ of botanical species are pink [13]. The Greek word 'rodon' means 'red' [7].

Roses are usually small or medium sized shrubs (from 20 to $300 \mathrm{~cm}$ ) with spiny or stiff bristles shoots [2]. Stems are upright, leaning or trailing-climbing on the ground. Their leaves position is alternate, the leaves are imparipinnate in most species, with serrate edges and stipules [4]. The leaflets (usually 5-7) are ovate [3]. Their flowers may be single, panicle, or in compound corymbs inflorescences, which are differentiated at the apex of the short-stems. The flower's components are held together by jar-shaped receptacle. The number of sepals and petals are 5, with many stamens and pistils. The shape of petals is generally broad, obovate mostly obcordate apex [4]. The color of the varieties is very wide - except for blue [8]. Their flowering time are usually between May and June [2]. The fleshy accessory fruit group is developed (so-called rose hips), which contain more hard-shelled achene. They are most often red [21]. The seeds are 4-5 mm long, irregularly angular with hard seed coat [19]. Drupe fruit may also occur within the Rosoidea subfamily. Several species spread successfully with vegetative organs (stolon, root sprouts) [6]. Botanists distinguish between 100 and 200 species [15]. The number of varieties is around ten thousand [22], and the breeding begin more thousand years ago [20].

\section{Rose petals in nutrition}

Pliny the Younger already mentions many uses for rose petals, leaves and stems. Rose oil and rose water were used in ancient times for stomach problems, tonsillitis, alleviating headaches and fever, sore throats, and externally for the eyes and skin. It became one of the most important medicinal plants in the Middle Ages, and the medicinal importance is also mentioned in the Hungarian herbals from the $18^{\text {th }}$ century [17]. Pharmacy rose (Rosa gallica var. officinalis) is also suitable for treating similar health problems according to John Gerard [10]. The following species

\footnotetext{
* Corresponding author. Tel.: +36 76517 655;

E-mail address: ecseri.karoly@kvk.uni-neumann.hu
} 
may be used in the production of essential oils: Rosa $\times$ damascena, Rosa $\times$ centifolia, Rosa gallica. Approximately 3.000-5.000 fresh petals are needed for $1 \mathrm{~kg}$ essential oil (Aetheroleum Rosae) production by steam distillation. Main constituents of oil are aldehydes and open-chain alcohols [16]. The main ingredients are: geraniol, citronellol, nerol, linalool, farnesol, phenylethanol, pelargonic acid. It can be used to flavor and improve the aroma of perfume, liqueur and possibly medicines in perfume industry [1].

Fragrant varieties should be used for consumption. The petals can be conserved by drying and sweetening. Petals can be candied, but it can be used to make jelly, jam, desserts and wine. Pharmacy rose (Rosa gallica var. officinalis) was the first taxon used for rose oil and rose water. The Damascus rose (Rosa $\times$ damascena) was also bred from this species later. One of its varieties ('Trigintipetala') is cultivated in Bulgaria [5]. It takes about 10.000 flowers to produce 25 milliliters oil [10]. Petals have antiviral and antimicrobial properties and used to contract wounds. They have a sedative, stress reliving effect on compresses. It stimulates the nervous system and reduces depression. It is ingredient is spice mixes and a flavoring component for Turkish sweets, sherbets, ice creams, pick-me-ups and desserts, but can also be used is salads, wines, punches and fruits [7].

Due to its nutritional value, Rosa odorata is a prominent rose flower for consumption. The total phenol content of this species is $5.02 \mathrm{~g}$ gallic acid $/ \mathrm{kg}$ fresh weight. This value is the third highest among the 12 flower species. Only carnation and pansy contain higher amounts of phenolic compounds [18]. Strong antioxidant activity can also be observed in fragrant rose, due to the high polyphenol content [12]. The total flavonoid content is also significant (2.04 g routine/kg fresh weight) in this species [18].

Rosa rugosa is similarly significant in polyphenol and flavonoid content. It contains $92.164 \mathrm{mg}$ catechin equivalents/g, and this value is the second highest among the 19 Chinese edible flower species (only the polyphenol content of woody peony - Paeonia suffruticosa - is higher). Therefore, this species also has outstanding free radical scavenging ability $(94.244 \%)$, which is higher than green tea (Camellia sinensis) [24]. 5 types of phenolic acids and 6 types of flavonoids have been identified, and the antioxidant and antimicrobial activity of this species has also been confirmed. Petals have a high antiproliferative effect on breast cancer (T47D) and cervical tumor (HeLa) types [14].

The soluble free gallic acid content of Rosa sinensis is $6.873 \mathrm{mg} / \mathrm{g}$ distilled water. This phenolic compound was not found in the flowers of Chrysanthemum morifolium or Prunus persica. The total phenolic composition showed a strong correlation with antioxidant capacity [23].

Rosa damascena is used for consumption in Thailand. Petals in curry, salads or vegetables are able to treat colds or stomach complaints according to locals [9].

[11] stated a high source of natural antioxidants in case of Rosa rugosa, therefore petals are useful as a medicine and as a functional food for the prevention of disease and oxidative stress.

The petals of Rosa odorata is low in nutrients. However, in term of potassium content (1969 $\mathrm{mg} / \mathrm{kg}$ fresh weight), it is higher than similar values for some fruits (for example pears: $1260 \mathrm{mg} / \mathrm{kg}$, raspberries: $1780 \mathrm{mg} / \mathrm{kg}$ fresh weight) and vegetables (cucumbers, zucchini). In terms of crude protein content $(2.66 \mathrm{~g} / \mathrm{kg}$ fresh weight), this species is also similar to the protein content of vegetables and fruits [18].

[25] stated that among the 65 edible flower species, roses (Rosa centifolia, Rosa chinensis, Rosa gallica, Rosa rugosa) have very high antioxidant capacity, which justifies their use as a functional food in reducting oxidative stress. In addition, extremely high total phenolic content (312 mg gallic acid equivalent/g sample) was observed for Rosa rugosa.

\section{Acknowledgment}

Thank you for the support of the research carried out in the framework of the EFOP-3.6.2-162017-00012 „Developing a functional, healthy and safe food product chain model from field to table in a thematic research network". The project is funded by the Hungarian State and the European Union, co-financed by the European Social Fund, and is part of the Széchenyi 2020 program. 


\section{References}

[1] BÁRÁNY L. (föszerk.) (2002): Magyar Nagylexikon. Tizenötödik kötet. Magyar Nagylexikon Kiadó, Budapest. p. 644.

[2] BARTHA D. (2018): Magyarország fa- és cserjefajai. Mezőgazda Lap- és Könyvkiadó Kft., Budapest. p. 196.

[3] BRICKELL, Ch. (2003): DSZNÖVÉNY ENCIKLOPÉDIA. Az Angol Királyi Kertészeti Társaság kézikönyve. Urbis Könyvkiadó, Budapest. pp. 587-593.

[4] GENCSI L. - VANCSURA R. (1992): DENDROLÓGIA. Erdészeti Növénytan II. Mezőgazda Kiadó, Budapest. pp. 489-495

[5] HOLMES, C. (2015): Kerti füszernövények. Kézikönyv ínyenc kertészeknek. Kossuth Kiadó, Kína. pp. 155-159.

[6] HORTOBÁGYI T. (szerk.) (1986): AGROBOTANIKA. Harmadik, átdolgozott kiadás. Mezőgazdasági Kiadó, Budapest. pp. 356-357.

[7] HURST, K. (2016): A természet kincsei. Gyógynövények. 150 faj sokrétű bemutatása. Saxum Könyvkiadó, Kína. p. 161.

[8] JÁVORKA S. - CSAPODY V. (1962): Kerti virágaink. Közép-európai dísznövények színes atlasza. Mezőgazdasági Kiadó, Budapest. pp. 55-56.

[9] KAISSON, O., KONCZAK, I. and SIRIAMORNPUN, S. (2012): Potential health enhancing properties of edible flowers from Thailand. Food Research International. Vol. 46. pp. 563-571.

[10] LAWS, B. (2012): Ötven növény, amely megváltoztatta a történelmet. Kossuth Kiadó, Budapest. pp. 162-165.

[11] LI, A-N., LI, S., LI, H-B., XU, D-P., XU, X-R. and CHEN, F. (2014): Total phenolic contents and antioxidant capacities of 51 edible and wild flowers. Journal of Functional Foods. Vol. 6. pp. 319-330.

[12] LOIZZO, M. R., PUGLIESE, A., BONESI, M., TENUTA, M. C., MENICHINI, F., XIAO, J. and TUNDIS, R (2016): Edible Flowers: A Rich Source of Phytochemicals with Antioxidant and Hypoglycemic Properties. Journal of Agricultural and Food Chemistry. Vol. 64. No. 12. pp. 2467-2474.

[13] MÁRK G. (2004): Magyar rózsák könyve. Mezőgazda Kiadó, Budapest. pp. 12-13, 17.

[14] NOWAK, R., OLECH, M., PECIO, Ł., OLESZEK, W., LOS, R., MALM, A. and RZYMOWSKA, J. (2014): Cytotoxic, antioxidant, antimicrobial properties and chemical composition of rose petals. Journal of the Science of Food and Agriculture. Vol. 94. pp. 560-567.

[15] PARKER, J., MALONE, M. (2006): FLÓRA. A világ legnagyobb kertészeti enciklopédiája. II. kötet. Athenaeum 2000 Kiadó, Budapest. pp. 1212-1281.

[16] RÁCZ G. - RÁCZ-KOTILLA E. - SZABÓ L. Gy. (2012): Gyógynövények ismerete. A fitoterápia és az alternatív medicina alapjai. Galenus Kiadó, Budapest. pp. 356-358.

[17] RÁCZ J. (2013): Növénynevek enciklopédiája. Az elnevezések eredete, a növények kultúrtörténete és élettani hatása. Tinta könyvkiadó, Budapest. pp. 638-640.

[18] ROP, O., MLCEK, J., JURIKOVA, T., NEUGEBAUEROVA, J. and VABKOVA, J. (2012): Edible Flowers - A New Promising Source of Mineral Elements in Human Nutrition. Molecules. Vol. 17. pp. 6672-6683.

[19] SCHERMANN Sz. (1967): Magismeret I. Akadémiai Kiadó, Budapest. p. 640.

[20] SCHMIDT G. - TÓTH I. (2006): Kertészeti dendrológia. Mezőgazda Kiadó, Budapest. pp. 181-187.

[21] TÓTH I. (2012): Lomblevelü díszfák, díszcserjék kézikönyve. Tarkavirág kereskedelmi és szolgáltató kft., Dunaharaszti. pp. 522-536.

[22] UJHELYI P. (szerk.) (2006): Élővilág Enciklopédia. A Kárpát-medence gombái és növényei. Kossuth Kiadó, Budapest. pp. 327-334.

[23] XIONG, L., YANG, J., JIANG, Y., LU, B., HU, Y., ZHOU, F., MAO, S. and SHEN, C. (2014): Phenolic Compounds and Antioxidant Capacities of 10 Common Edible Flowers from China. Journal of Food Science. Vol. 79 . Issue 4. pp. C517-C525.

[24] ZENG, Y., DENG, M., LV, Z. and PENG, Y. (2014): Evaluation of antioxidant activites of extracts from 19 Chinese edible flowers. SpringerPlus. Vol. 3. Article: 315.

[25] ZHENG, J., YU, X., MANINDER M. \& XU, B. (2018): Total phenolics and antioxidants profiles of commonly consumed edible flowers in China. International Journal of Food Properties. Vol. 21. Nr. 1. pp. 1524-1540. 